\title{
Quality of Life in Swallowing Disorders after Nonsurgical Treatment for Head and Neck Cancer
}

\author{
Marta Halina Silveira ${ }^{1}$ Rogerio A. Dedivitis ${ }^{2}$ Débora Santos Queija ${ }^{1}$ Paulo César Nascimento ${ }^{3}$ \\ ${ }^{1}$ Department of Otorhinolaryngology-Head and Neck Surgery, \\ Universidade Metropolitana de Santos, Santos, São Paulo, Brazil \\ 2 Department of Head and Neck Surgery, Hospital das Clinicas, \\ University of Sao Paulo School of Medicine, Santos, São Paulo, Brazil \\ ${ }^{3}$ Department of Radiotherapy, Irmandade da Santa Casa da \\ Misericórdia de Santos, Santos, São Paulo, Brazil \\ Address for correspondence Rogerio A. Dedivitis, MD, MSc, \\ Department of Head and Neck Surgery, Hospital das Clinicas, \\ University of Sao Paulo School of Medicine, Rua Dr. Olinto Rodrigues \\ Dantas, 343 conj. 92, Santos, SP 11050-220, Brazil \\ (e-mail: dedivitis.hns@uol.com.br).
} Int Arch Otorhinolaryngol 2015;19:46-54.

\begin{abstract}
Keywords

- head and neck neoplasms

- dysphagia

- deglutition disorders

- quality of life

- radiotherapy

- chemotherapy

Introduction Radiotherapy or chemoradiotherapy can result in severe swallowing disorders with potential risk for aspiration and can negatively impact the patient's quality of life (QOL).

Objective To assess swallowing-related $\mathrm{QOL}$ in patients who underwent radiotherapy/ chemoradiotherapy for head and neck cancer.

Methods We interviewed 110 patients ( 85 men and 25 women) who had undergone exclusive radiotherapy (25.5\%) or concomitant chemoradiotherapy (74.5\%) from 6 to 12 months before the study. The Quality of Life in Swallowing Disorders (SWAL-QOL) questionnaire was employed to evaluate dysphagia-related QOL.

Results The QOL was reduced in all domains for all patients. The scores were worse among men. There was a relationship between oral cavity as the primary cancer site and the fatigue domain and also between advanced cancer stage and the impact of food selection, communication, and social function domains. Chemoradiotherapy association, the presence of nasogastric tube and tracheotomy, and the persistence of alcoholism and smoking had also a negative effect on the QOL.

Conclusions According to the SWAL-QOL questionnaire, the dysphagia-related impact on QOL was observed 6 to 12 months after the treatment ended.
\end{abstract}

\section{Introduction}

Use of radiotherapy with or without chemotherapy as primary treatment for cancer of the head and neck has increased over the past decades. Although the primary goal of treatment is to cure, a perceived additional benefit is the preservation of the organs of the head and neck. Thus, swallowing function after treatment is of major interest. ${ }^{1}$ However, the current literature indicates that, despite the anatomical preservation of the structures, swallowing function is not maintained at normal levels after treat- ment..$^{2-4}$ Some alternative feeding route can be necessary due to dysphagia during or after the oncological treatment, which can impair the patient's quality of life (QOL). ${ }^{5-7}$

Although many modalities could demonstrate organic dysfunction in swallowing, the patient's subjective self-perception seems the most significant outcome measure. A questionnaire for measuring a patient's perception of dysphagia and its effect on QOL was developed. ${ }^{5-7}$ This tool, known as the Quality of Life in Swallowing Disorders $(\mathrm{SWAL}-\mathrm{QOL})^{8-10}$ questionnaire, is validated, reliable, and received

July 12,2014

accepted

October 11, 2014

published online

December 5, 2014
DOI http://dx.doi.org/

10.1055/s-0034-1395790. ISSN $1809-9777$.
Copyright $(2015$ by Thieme Publicações License terms Ltda, Rio de Janeiro, Brazil

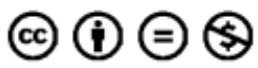


reproducible for assessing the perception of dysphagia and has been validated in Brazilian Portuguese. ${ }^{11}$ Recently, the psychometric and clinical validity of the SWAL-QOL questionnaire was tested in patients with oral and oropharyngeal cancer and was found to be reliable, clinically feasible, and useful for evaluating swallowing problems. A difference of 12 points or more in score was considered clinically and statistically relevant in comparing groups of patients. ${ }^{12}$

The aim of this study is to evaluate swallowing-related QOL in patients who underwent radiotherapy or chemoradiotherapy for treatment of head and neck tumors.

\section{Methods}

This cross-sectional study consisted of 110 previously untreated patients from 21 to 87 years old (median, 61; 77.3\% men and $22.7 \%$ women) who underwent radiotherapy or concomitant chemoradiotherapy for the treatment of head and neck squamous cell carcinoma. The protocol was approved by the research board, and the patients gave their consent for participation in this study. They were prospectively enrolled in the study from 6 to 12 months after the treatment ended. All patients were evaluated between May and August 2012 at the Service of Radiotherapy of the institution in which treatment was performed. All patients completed the study. Their data are presented in - Table 1.

The patients were asked to fill out the SWAL-QOL questionnaire previously validated in Brazilian Portuguese. ${ }^{11}$ It is a 44-item tool for assessing swallowing-related WOL, using 11 domains, including burden, desire, eating duration, symptoms frequency, food selection, communication, fear, mental health, sleep, social, and fatigue. Scores were calculated from each SWAL-QOL domain on a scale from 0 to 100 , with a score of 100 representing the most favorable state.

The questionnaires were filled out once in a cross-sectional analysis by the patient alone or with the help of a relative or an interviewer if the patient was illiterate. Epidemiologic and clinicopathologic details were obtained from the charts.

Central trend and variability measurements were used to describe the numerical variables and the frequency distributions for categorical variables. To investigate associations between numerical variables (measurements) in groups with two categories, the nonparametric Mann-Whitney $U$ test was applied; with three or more categories, the nonparametric Kruskal-Wallis test was used. When statistically significant differences were identified, the significance value was adjusted by means of Bonferroni correction. A significance level of $5 \%$ was used for all statistical tests, unless adjusted through Bonferroni correction, in which cases new significance values are presented. The IBM-SPSS statistical computer software (IBM-SPSS Statistics GradPack, Armonk, USA), version 21.0, was used to perform the statistical analysis.

\section{Results}

The SWAL-QOL questionnaire indicated low median levels, generally with worse scores for desire, mental health, burden, and eating duration domains (-Table 2 ).
Table 1 Patient characteristics $(n=110)$

\begin{tabular}{|c|c|c|}
\hline Variable & Category & $n(\%)$ \\
\hline Age $(y)$ & $\begin{array}{l}\text { Minimum-maximum } \\
\text { 25th percentile } \\
\text { 50th percentile (median) } \\
\text { 75th percentile }\end{array}$ & $\begin{array}{l}21-87 \\
56.0 \\
62.0 \\
69.0\end{array}$ \\
\hline Sex & $\begin{array}{l}\text { Female } \\
\text { Male }\end{array}$ & $\begin{array}{l}25(22.70) \\
85(77.30)\end{array}$ \\
\hline Tumor site & $\begin{array}{l}\text { Oral cavity } \\
\text { Oropharynx } \\
\text { Nasopharynx } \\
\text { Larynx } \\
\text { Hypopharynx } \\
\text { Unknown primary }\end{array}$ & $\begin{array}{l}8(7.30) \\
33(30.0) \\
9(8.20) \\
24(21.80) \\
10(9.10) \\
26(23.60)\end{array}$ \\
\hline$T$ & $\begin{array}{l}\text { T0 } \\
\text { T1 } \\
\text { T2 } \\
\text { T3 } \\
\text { T4 }\end{array}$ & $\begin{array}{l}2(1.80) \\
27(24.50) \\
24(21.80) \\
28(25.50) \\
29(26.40)\end{array}$ \\
\hline $\mathrm{N}$ & $\begin{array}{l}\text { N0 } \\
\text { N1 } \\
\text { N2a } \\
\text { N2b } \\
\text { N2c } \\
\text { N3 } \\
\end{array}$ & $\begin{array}{l}63(57.30) \\
9(8.20) \\
16(14.50) \\
10(9.10) \\
7(6.40) \\
5(4.50)\end{array}$ \\
\hline $\begin{array}{l}\text { Treatment } \\
\text { modalities }\end{array}$ & $\begin{array}{l}\text { Exclusively } \\
\text { conventional } \\
\text { radiotherapy } \\
\text { Chemoradiation }\end{array}$ & $\begin{array}{l}28(25.50) \\
82(74.50)\end{array}$ \\
\hline Nasogastric tube & $\begin{array}{l}\text { No } \\
\text { During radiotherapy } \\
\text { During and } \\
\text { after radiotherapy } \\
\text { In use }\end{array}$ & $\begin{array}{l}77(70) \\
9(8.20) \\
16(14.50) \\
8(7.30)\end{array}$ \\
\hline Tracheotomy & $\begin{array}{l}\text { No } \\
\text { Definitive } \\
\text { During radiotherapy } \\
\text { Under temporary use }\end{array}$ & $\begin{array}{l}85(77.30) \\
8(7.30) \\
13(11.80) \\
4(3.60)\end{array}$ \\
\hline Keep smoking & $\begin{array}{l}\text { No } \\
\text { Yes }\end{array}$ & $\begin{array}{l}66(60) \\
44(40)\end{array}$ \\
\hline Keep drinking & $\begin{array}{l}\text { No } \\
\text { Yes }\end{array}$ & $\begin{array}{l}80(72.70) \\
30(27.30)\end{array}$ \\
\hline
\end{tabular}

The association between sex and the SWAL-QOL questionnaire was verified and the scores showed higher QOL impact among men in almost all domains, including eating duration $(p=0.003)$, mental health $(p=0.006)$, and symptom frequency $(p=0.022)$. Other domains also presented differences of more than 12 points but lacked statistical significance (desire, communication, fear, and sleep; - Table 3).

The primary tumor site was significantly correlated between oral cavity tumors and the fatigue domain $(p=0.041)$. There was a difference of more than 12 points in the communication domain for the larynx in comparison with other sites, which was not statistically significant.

Patients with advanced primary tumors (T4) had the worst results for the food selection $(p=0.037)$, communication $(p=0.022)$, and social $(p=0.021)$ domains. There were 
Table 2 Quality of life in swallowing disorders (SWAL-QOL)

\begin{tabular}{|c|c|c|c|c|c|}
\hline Variable & $n$ & min.-max. & 25th percentile & 50th percentile & 75th percentile \\
\hline Burden & 110 & $0-100$ & 25 & 50 & 100 \\
\hline Desire & 110 & $0-100$ & 16 & 41 & 66 \\
\hline Eating duration & 110 & $0-100$ & 25 & 25 & 75 \\
\hline Symptom frequency & 110 & $3.5-100$ & 44 & 60 & 82 \\
\hline Food selection & 110 & $0-100$ & 25 & 75 & 100 \\
\hline Communication & 110 & $0-100$ & 25 & 75 & 100 \\
\hline Fear & 110 & $6.2-100$ & 37 & 75 & 93 \\
\hline Mental health & 110 & $0-100$ & 20 & 60 & 100 \\
\hline Social & 110 & $0-100$ & 38 & 75 & 100 \\
\hline Sleep & 110 & $0-100$ & 50 & 100 & 100 \\
\hline Fatigue & 110 & $0-100$ & 41 & 75 & 100 \\
\hline
\end{tabular}

Abbreviations: max., maximum; min., minimum; SWAL-QOL, Quality of Life in Swallowing Disorders questionnaire.

more than 12-point differences in scores for the burden, desire, eating duration, and mental health domains, suggesting that those patients had a worse QOL. On the other hand, the association between the regional stage $(\mathrm{N})$ and the SWALQOL did not present a statistically significant correlation in the questionnaire domains.

A total of 82 of the 110 patients underwent chemotherapy concomitant to the radiotherapy. The result in the burden domain was worse in this group $(p=0.020)$ than in the group of exclusive radiotherapy. The scores presented a difference for the communication $(50 \times 25)$ and fatigue $(27.08 \times 50)$ domains but lacked statistical significance.

The presence of a nasogastric tube impacted on almost all domains, mainly eating duration ( $p<0.001$ ), symptom frequency $(p<0.001)$, food selection $(p<0.001)$, mental health $(p<0.001)$, and social $(p<0.001$; - Table 4). Bonferroni correction showed differences in the eating duration, frequency of symptoms, food selection, and mental health domains. Furthermore, the use of nasogastric tube during and after radiotherapy also interfered with some QOL aspects ( - Table $\mathbf{5}$ ).

The questionnaire also identified a statistically significant impact of the definitive tracheotomy in the communication domain ( $p<0.001$; - Tables 6 and 7 ).

Alcohol consumption had a negative influence on QOL in the domains of communication $(p=0.020)$ and mental health $(p=0.031)$. The burden $(25 \times 9.38)$, social $(40 \times 33.75)$, and fatigue $(52 \times 33.3)$ domains were identified via differences in scores as well. On the other hand, patients who continued to smoke presented worse results on the burden $(p=0.003)$, mental health $(p=0.030)$, and fatigue $(p=0.028)$ domains.

\section{Discussion}

The incidence of posttreatment dysphagia in patients with head and neck cancer has previously been reported to be between 50 and $60 \%{ }^{13,14}$ Furthermore, it has been estimated that 30 to $50 \%$ of patients with head and neck cancer demonstrate some degree of malnutrition. ${ }^{5}$ The combination of dysphagia with poor nutrition, significant weight loss, and impaired immune function often results in cachexia, fatigue, high susceptibility to infection, poor wound healing, or death. ${ }^{5,15}$

The most common acute side effects of chemoradiotherapy are mucositis, pain, dermatitis, xerostomia, loss of taste, hoarseness, weight loss, myelosuppression, nausea, and dysphagia. The most frequent late side effects are xerostomia, loss of taste, fibrosis, trismus, and dysphagia. Dysphagia has a potential for aspiration and death due to aspiration pneumonia. ${ }^{5,16}$ Thus, it is important to evaluate the short-, medium-, and long-term functional outcomes of radiotherapy treatment associated or not with chemotherapy. Some factors related to pretreatment status, such as weight, staging, primary tumor site, and treatment modality, interfere in the outcome and the QOL. ${ }^{17-19}$

We found the median scores of SWAL-QOL for the whole group showed some loss in almost all domains, even 6 to 12 months following treatment completion. Some aspects specifically related to feeding, such as desire, eating duration, burden, food selection, and fear, seemed to have relevance for those patients, jeopardizing their mental health. A person with dysphagia spends a longer time eating, presents lower skill to eat varied food, and can be afraid, constrained, and/or incapable of eating in public, remaining socially isolated and depressed. ${ }^{14}$

Men are more prone to be affected than women, showing a greater difficulty to adapt.

Dysphagia is common after the treatment of head and neck cancer; mucositis, nausea, loss of eating desire, taste changing, and xerostomia can make eating difficult and cause fatigue, jeopardizing the QOL. ${ }^{20}$ The fatigue domain presented a higher impact among patients with oral cancer. In fact, eating for a longer time can cause a feeling of fatigue. On the other hand, laryngeal cancer showed an impact on communication, due to mucosa dryness, fibrosis, muscular atrophy, and edema, which are consequent to radiotherapy 
Table 3 Association between SWAL-QOL and sex

\begin{tabular}{|c|c|c|c|c|c|c|c|}
\hline Variable & Sex & $n$ & min.-max. & 25th percentile & 50th percentile & 75th percentile & $p$ \\
\hline \multirow[t]{3}{*}{ Burden } & Female & 25 & $0-100$ & 50 & 62 & 100 & \multirow[t]{3}{*}{$0.038^{a}$} \\
\hline & Male & 85 & $0-100$ & 25 & 50 & 93.75 & \\
\hline & Total & 110 & $0-100$ & 25 & 50 & 100 & \\
\hline \multirow[t]{3}{*}{ Desire } & Female & 25 & $16.60-100$ & 29 & 41 & 75 & \multirow[t]{3}{*}{0.120} \\
\hline & Male & 85 & $0-100$ & 16 & 33 & 66 & \\
\hline & Total & 110 & $0-100$ & 16 & 41 & 66 & \\
\hline \multirow[t]{3}{*}{ Eating duration } & Female & 25 & $25-100$ & 25 & 50 & 100 & \multirow[t]{3}{*}{$0.003^{a}$} \\
\hline & Male & 85 & $0-100$ & 25 & 50 & 50 & \\
\hline & Total & 110 & $0-100$ & 25 & 25 & 75 & \\
\hline \multirow[t]{3}{*}{ Symptom frequency } & Female & 25 & $26.70-100$ & 53 & 76 & 83 & \multirow[t]{3}{*}{$0.022^{a}$} \\
\hline & Male & 85 & $3.50-100$ & 39 & 57 & 78 & \\
\hline & Total & 110 & $3.50-100$ & 44 & 60 & 82 & \\
\hline \multirow[t]{3}{*}{ Food selection } & Female & 25 & $25-100$ & 25 & 75 & 100 & \multirow[t]{3}{*}{0.287} \\
\hline & Male & 85 & $0-100$ & 25 & 75 & 100 & \\
\hline & Total & 110 & $0-100$ & 25 & 75 & 100 & \\
\hline \multirow[t]{3}{*}{ Communication } & Female & 25 & $0-100$ & 50 & 75 & 100 & \multirow[t]{3}{*}{0.204} \\
\hline & Male & 85 & $0-100$ & 25 & 75 & 100 & \\
\hline & Total & 110 & $0-100$ & 25 & 75 & 100 & \\
\hline \multirow[t]{3}{*}{ Fear } & Female & 25 & $25-100$ & 46 & 81 & 100 & \multirow[t]{3}{*}{0.111} \\
\hline & Male & 85 & $6.20-100$ & 34 & 75 & 87 & \\
\hline & Total & 110 & $6.20-100$ & 37 & 75 & 93 & \\
\hline \multirow[t]{3}{*}{ Mental health } & Female & 25 & $10-100$ & 55 & 90 & 100 & \multirow[t]{3}{*}{$0.006^{a}$} \\
\hline & Male & 85 & $0-100$ & 12 & 50 & 100 & \\
\hline & Total & 110 & $0-100$ & 20 & 60 & 100 & \\
\hline \multirow[t]{3}{*}{ Social } & Female & 25 & $25-100$ & 70 & 85 & 100 & \multirow[t]{3}{*}{$0.034^{\mathrm{a}}$} \\
\hline & Male & 85 & $0-100$ & 35 & 70 & 100 & \\
\hline & Total & 110 & $0-100$ & 38 & 75 & 100 & \\
\hline \multirow[t]{3}{*}{ Sleep } & Female & 25 & $0-100$ & 87 & 100 & 100 & \multirow[t]{3}{*}{0.051} \\
\hline & Male & 85 & $0-100$ & 50 & 100 & 100 & \\
\hline & Total & 110 & $0-100$ & 50 & 100 & 100 & \\
\hline \multirow[t]{3}{*}{ Fatigue } & Female & 25 & $25-100$ & 70 & 83 & 100 & \multirow[t]{3}{*}{$0.043^{a}$} \\
\hline & Male & 85 & $0-100$ & 33 & 75 & 100 & \\
\hline & Total & 110 & $0-100$ & 41 & 75 & 100 & \\
\hline
\end{tabular}

Abbreviations: max., maximum; min., minimum; SWAL-QOL, Quality of Life in Swallowing Disorders questionnaire. Note: $p$ value according to Mann-Whitney test.

${ }^{\mathrm{a}} p<0.05$.

and can affect vocal production. ${ }^{21-23}$ In addition, tumor location itself has some importance.

Patients with advanced primary tumor presented worse results. In contrast, the stratification of the patients according to the cervical staging $(\mathrm{N})$ had no relationship with the QOL in our study, but other studies found that bilateral neck irradiation contributes to worse functional outcome. ${ }^{18}$

Most of our patients (74.5\%) underwent concomitant chemoradiotherapy with greater harm on the burden domain. The effects of late radiation-induced toxicity on deglu- tition and the salivary glands are more intense in the first 12 months after treatment and decrease gradually after 18 to 24 months. ${ }^{24}$ It should also be mentioned that dysphagia and QOL are damaged in advanced tumors, worsen during chemoradiotherapy, and improve 6 months after the treatment. ${ }^{25}$ We studied patients whose period after the treatment conclusion varied from 6 to 12 months. When the SWAL-QOL was associated with the type of treatment, the first aspect accentuated was the domain of burden (which is related to dysphagia), followed by the domains of fatigue (related to feeding 
50 QOL after Head and Neck Cancer Silveira et al.

Table 4 Association between SWAL-QOL and the presence of nasogastric tube

\begin{tabular}{|c|c|c|c|c|c|c|c|}
\hline Variable & $\begin{array}{l}\text { Nasogastric } \\
\text { tube }\end{array}$ & $n$ & $\min .-\max$ & 25th percentile & 50th percentile & 75th percentile & $p$ \\
\hline \multirow[t]{5}{*}{ Burden } & No & 77 & $0-100$ & 25 & 50 & 100 & \multirow[t]{3}{*}{$0.032^{a}$} \\
\hline & During RT & 9 & $0-100$ & 0 & 50 & 62 & \\
\hline & During/after RT & 16 & $12-100$ & 25 & 37 & 68 & \\
\hline & In use & 8 & $0-75$ & 0 & 25 & 34 & \\
\hline & Total & 110 & $0-100$ & 25 & 50 & 100 & \\
\hline \multirow[t]{5}{*}{ Desire } & No & 77 & $0-100$ & 25 & 41 & 75 & \multirow[t]{5}{*}{0.093} \\
\hline & During RT & 9 & $0-66$ & 8 & 41 & 58 & \\
\hline & During/after RT & 16 & $0-100$ & 16 & 41 & 50 & \\
\hline & In use & 8 & $0-75$ & 2 & 12 & 60 & \\
\hline & Total & 110 & $0-100$ & 16 & 4 & 66 & \\
\hline \multirow[t]{5}{*}{ Eating duration } & No & 77 & $0-100$ & 25 & 50 & 81 & \multirow[t]{3}{*}{$<0.001^{\mathrm{a}}$} \\
\hline & During RT & 9 & $0-50$ & 0 & 25 & 37 & \\
\hline & During/after RT & 16 & $0-100$ & 25 & 25 & 25 & \\
\hline & In use & 8 & $0-50$ & 0 & 0 & 18 & \\
\hline & Total & 110 & $0-100$ & 25 & 25 & 75 & \\
\hline \multirow{5}{*}{$\begin{array}{l}\text { Symptom } \\
\text { frequency }\end{array}$} & No & 77 & $7.10-100$ & 52 & 66 & 85 & \\
\hline & During RT & 9 & $25-66$ & 25 & 46 & 53 & \multirow[t]{2}{*}{$<0.001^{a}$} \\
\hline & During/after RT & 16 & $26.70-83.90$ & 38 & 56 & 69 & \\
\hline & In use & 8 & $3.50-71.40$ & 10 & 22 & 46 & \\
\hline & Total & 110 & $3.50-100$ & 44 & 60 & 82 & \\
\hline \multirow[t]{5}{*}{ Food selection } & No & 77 & $0-100$ & 25 & 75 & 100 & \multirow[t]{3}{*}{$<0.001^{\mathrm{a}}$} \\
\hline & During RT & 9 & $0-100$ & 25 & 25 & 75 & \\
\hline & During/after RT & 16 & $25-100$ & 25 & 37 & 75 & \\
\hline & In use & 8 & $0-50$ & 0 & 0 & 43 & \\
\hline & Total & 110 & $0-100$ & 25 & 75 & 100 & \\
\hline \multirow[t]{5}{*}{ Communication } & No & 77 & $0-100$ & 50 & 75 & 100 & \multirow[t]{3}{*}{$0.031^{a}$} \\
\hline & During RT & 9 & $0-100$ & 0 & 50 & 100 & \\
\hline & During/after RT & 16 & $0-100$ & 6 & 62 & 100 & \\
\hline & In use & 8 & $0-100$ & 0 & 18 & 50 & \\
\hline & Total & 110 & $0-100$ & 25 & 75 & 100 & \\
\hline \multirow[t]{5}{*}{ Fear } & No & 77 & $12.50-100$ & 56 & 81 & 100 & \multirow[t]{3}{*}{$0.001^{\mathrm{a}}$} \\
\hline & During RT & 9 & $18.70-93.70$ & 25 & 25 & 81 & \\
\hline & During/after RT & 16 & $25-100$ & 32 & 50 & 85 & \\
\hline & In use & 8 & $6.20-93.70$ & 12 & 25 & 65 & \\
\hline & Total & 110 & $6.20-100$ & 37 & 75 & 93 & \\
\hline \multirow[t]{5}{*}{ Mental health } & No & 77 & $0-100$ & 40 & 80 & 100 & \multirow[t]{3}{*}{$<0.001^{a}$} \\
\hline & During RT & 9 & $0-75$ & 5 & 25 & 60 & \\
\hline & During/after RT & 16 & $0-100$ & 16 & 37 & 73 & \\
\hline & In use & 8 & $0-50$ & 0 & 7 & 23 & \\
\hline & Total & 110 & $0-100$ & 20 & 60 & 100 & \\
\hline \multirow[t]{3}{*}{ Social } & No & 77 & $0-100$ & 57 & 85 & 100 & \multirow[t]{3}{*}{$<0.001^{a}$} \\
\hline & During RT & 9 & $35-75$ & 35 & 40 & 72 & \\
\hline & During/after RT & 16 & $0-100$ & 25 & 47 & 82 & \\
\hline
\end{tabular}


Table 4 (Continued)

\begin{tabular}{|c|c|c|c|c|c|c|c|}
\hline Variable & $\begin{array}{l}\text { Nasogastric } \\
\text { tube }\end{array}$ & $n$ & min.-max. & 25th percentile & 50th percentile & 75th percentile & $p$ \\
\hline & In use & 8 & $0-35$ & 0 & 12 & 25 & \\
\hline & Total & 110 & $0-100$ & 38 & 75 & 100 & \\
\hline \multirow[t]{5}{*}{ Sleep } & No & 77 & $0-100$ & 68 & 100 & 100 & \multirow[t]{5}{*}{0.458} \\
\hline & During RT & 9 & $25-100$ & 50 & 87 & 100 & \\
\hline & During/after RT & 16 & $25-100$ & 50 & 93 & 100 & \\
\hline & In use & 8 & $12.50-100$ & 50 & 75 & 100 & \\
\hline & Total & 110 & $0-100$ & 50 & 100 & 100 & \\
\hline \multirow[t]{5}{*}{ Fatigue } & No & 77 & $0-100$ & 62 & 83 & 100 & \multirow[t]{3}{*}{$0.001^{\mathrm{a}}$} \\
\hline & During RT & 9 & $0-100$ & 25 & 50 & 66 & \\
\hline & During/after RT & 16 & $0-100$ & 33 & 75 & 100 & \\
\hline & In use & 8 & $0-83.30$ & 8 & 25 & 62 & \\
\hline & Total & 110 & $0-100$ & 41 & 75 & 100 & \\
\hline
\end{tabular}

Abbreviations: max., maximum; min., minimum; RT, radiotherapy; SWAL-QOL, Quality of Life in Swallowing Disorders questionnaire. Note: $p$ value according to Kruskal-Wallis test.

${ }^{a} p<0.05$.

deficit) and communication (related to the tumor and treatment sequel).

The use of a nasogastric tube had an important impact on all domains of the questionnaire, worsening the QOL. A nasogastric tube changes the daily routine and needs special care. Furthermore, feeding time is longer than habitual, and as a result there are social isolation and mental health aspects to its use. The weight loss during and in the 3 months after radiotherapy is independently associated with the QOL in patients with head and neck cancer. ${ }^{26}$ The use of tracheotomy also affects the QOL, according to the questionnaire, mainly with regard to communication, mental health, and social life. These three domains are clearly related to each other in patients with tracheotomy. The communication domain showed a higher impact during temporary use and during the radiotherapy performance, whereas the social function and food selection domains more often identified definitive use. Food selection harm can be a consequence of posttreatment edema, which damages the pharyngeal transit and might require dietary adaptation to minimize the treatment sequela. ${ }^{23}$

Mental health was jeopardized among patients who continued to consume tobacco and alcohol. Such patients are prone to depression. The maintenance of those habits is responsible for a lower QOL. 17,18,27,28

Dysphagia is generally underdiagnosed or is not properly considered. Despite not replacing the clinical and instrumental evaluations, QOL questionnaires can contribute to evaluating specific aspects regarding the patient's well-being and

Table 5 Association between SWAL-QOL and the presence of nasogastric tube

\begin{tabular}{|l|l|l|l|l|l|l|}
\hline Variable & $\begin{array}{l}\text { Not during } \\
\text { radiotherapy }\end{array}$ & $\begin{array}{l}\text { Not during/ } \\
\text { after } \\
\text { radiotherapy }\end{array}$ & Not in use & $\begin{array}{l}\text { During radiotherapy } \\
\text { or during/after } \\
\text { radiotherapy }\end{array}$ & $\begin{array}{l}\text { During } \\
\text { radiotherapy } \\
\text { or in use }\end{array}$ & $\begin{array}{l}\text { During/after } \\
\text { radiotherapy } \\
\text { or in use }\end{array}$ \\
\hline Burden & 0.156 & 0.237 & 0.011 & 0.626 & 0.372 & 0.036 \\
\hline Eating duration & 0.015 & 0.061 & $<0.001^{\mathrm{a}}$ & 0.305 & 0.138 & $0.006^{\mathrm{a}}$ \\
\hline Symptom frequency & $0.003^{\mathrm{a}}$ & 0.030 & $<0.001^{\mathrm{a}}$ & 0.084 & 0.092 & 0.009 \\
\hline Food selection & 0.021 & 0.046 & $<0.001^{\mathrm{a}}$ & 0.373 & 0.070 & $0.006^{\mathrm{a}}$ \\
\hline Communication & 0.139 & 0.253 & 0.007 & 0.638 & 0.455 & 0.166 \\
\hline Fear & 0.013 & 0.139 & 0.002 & 0.228 & 0.324 & 0.059 \\
\hline Mental health & $0.005^{\mathrm{a}}$ & 0.020 & $<0.001^{\mathrm{a}}$ & 0.392 & 0.155 & 0.016 \\
\hline Social & $0.004^{\mathrm{a}}$ & 0.009 & $<0.001^{\mathrm{a}}$ & 0.886 & $0.001^{\mathrm{a}}$ & 0.011 \\
\hline Fatigue & $0.008^{\mathrm{a}}$ & 0.317 & $0.001^{\mathrm{a}}$ & 0.144 & 0.241 & 0.024 \\
\hline
\end{tabular}

Abbreviations: max., maximum; min., minimum; RT, radiotherapy; SWAL-QOL, Quality of Life in Swallowing Disorders questionnaire.

Note: $p$ value according to Bonferroni correction $(p=0.008512)$. 
52 QOL after Head and Neck Cancer Silveira et al.

Table 6 Association between SWAL-QOL and the presence of tracheotomy

\begin{tabular}{|c|c|c|c|c|c|c|c|}
\hline Variable & Tracheotomy & $n$ & min.-max. & 25th percentile & 50th percentile & 75th percentile & $p$ \\
\hline \multirow[t]{5}{*}{ Burden } & No & 85 & $0-100$ & 25 & 50 & 100 & \multirow[t]{3}{*}{$0.042^{a}$} \\
\hline & Definitive & 8 & $0-100$ & 0 & 6 & 43 & \\
\hline & $\begin{array}{l}\text { Temporary } \\
\text { during RT }\end{array}$ & 13 & $12.50-100$ & 25 & 37 & 50 & \\
\hline & Temporary use & 4 & $0-87.50$ & 6 & 50 & 84 & \\
\hline & Total & 110 & $0-100$ & 25 & 50 & 100 & \\
\hline \multirow[t]{5}{*}{ Desire } & No & 85 & $0-100$ & 20 & 41 & 70 & \multirow[t]{5}{*}{0.133} \\
\hline & Definitive & 8 & $0-50$ & 8 & 16 & 43 & \\
\hline & $\begin{array}{l}\text { Temporary } \\
\text { during RT }\end{array}$ & 13 & $0-100$ & 12 & 41 & 75 & \\
\hline & Temporary use & 4 & $0-83.30$ & 2 & 24 & 72 & \\
\hline & Total & 110 & $0-100$ & 16 & 41 & 66 & \\
\hline \multirow[t]{5}{*}{ Eating duration } & No & 85 & $0-100$ & 25 & 25 & 75 & \multirow[t]{3}{*}{0.153} \\
\hline & Definitive & 8 & $0-75$ & 6 & 25 & 43 & \\
\hline & $\begin{array}{l}\text { Temporary } \\
\text { during RT }\end{array}$ & 13 & $0-100$ & 25 & 25 & 37 & \\
\hline & Temporary use & 4 & $0-100$ & 0 & 12 & 81 & \\
\hline & Total & 110 & $0-100$ & 25 & 25 & 75 & \\
\hline \multirow{5}{*}{$\begin{array}{l}\text { Symptom } \\
\text { frequency }\end{array}$} & No & 85 & $7.10-100$ & 48 & 60 & 85 & \\
\hline & Definitive & 8 & $3.50-91$ & 24 & 44 & 63 & \multirow[t]{2}{*}{$0.042^{\mathrm{a}}$} \\
\hline & $\begin{array}{l}\text { Temporary } \\
\text { during RT }\end{array}$ & 13 & $26.70-75$ & 39 & 50 & 60 & \\
\hline & Temporary use & 4 & $8.90-78.50$ & 12 & 46 & 75 & \\
\hline & Total & 110 & $3.50-100$ & 44 & 60 & 82 & \\
\hline \multirow[t]{5}{*}{ Food selection } & No & 85 & $0-100$ & 25 & 75 & 100 & \multirow[t]{3}{*}{$0.019^{a}$} \\
\hline & Definitive & 8 & $0-75$ & 25 & 25 & 25 & \\
\hline & $\begin{array}{l}\text { Temporary } \\
\text { during RT }\end{array}$ & 13 & $0-100$ & 25 & 50 & 87 & \\
\hline & In temporary use & 4 & $0-75$ & 12 & 56 & 71 & \\
\hline & Total & 110 & $0-100$ & 25 & 75 & 100 & \\
\hline \multirow[t]{5}{*}{ Communication } & No & 85 & $0-100$ & 50 & 100 & 100 & \multirow[t]{3}{*}{$<0.001^{\mathrm{a}}$} \\
\hline & Definitive & 8 & $0-100$ & 6 & 50 & 50 & \\
\hline & $\begin{array}{l}\text { Temporary } \\
\text { during RT }\end{array}$ & 13 & $0-100$ & 0 & 25 & 62 & \\
\hline & Temporary use & 4 & $0-25$ & 0 & 0 & 18 & \\
\hline & Total & 110 & $0-100$ & 25 & 75 & 100 & \\
\hline \multirow[t]{5}{*}{ Fear } & No & 85 & $12.50-100$ & 46 & 81 & 100 & \multirow[t]{3}{*}{$0.022^{a}$} \\
\hline & Definitive & 8 & $6.20-93.70$ & 25 & 31 & 57 & \\
\hline & $\begin{array}{l}\text { Temporary } \\
\text { during RT }\end{array}$ & 13 & $25-100$ & 28 & 37 & 87 & \\
\hline & Temporary use & 4 & $25-100$ & 25 & 46 & 92 & \\
\hline & Total & 110 & $6.20-100$ & 37 & 75 & 93 & \\
\hline \multirow[t]{3}{*}{ Mental health } & No & 85 & $0-100$ & 25 & 70 & 100 & \multirow[t]{3}{*}{0.054} \\
\hline & Definitive & 8 & $5-100$ & 6 & 15 & 25 & \\
\hline & $\begin{array}{l}\text { Temporary } \\
\text { during RT }\end{array}$ & 13 & $10-100$ & 20 & 45 & 75 & \\
\hline
\end{tabular}


Table 6 (Continued)

\begin{tabular}{|c|c|c|c|c|c|c|c|}
\hline Variable & Tracheotomy & $n$ & min.-max. & 25th percentile & 50th percentile & 75th percentile & $p$ \\
\hline & Temporary use & 4 & $0-100$ & 0 & 35 & 92 & \\
\hline & Total & 110 & $0-100$ & 20 & 60 & 100 & \\
\hline \multirow[t]{5}{*}{ Social } & No & 85 & $0-100$ & 40 & 75 & 100 & \multirow[t]{3}{*}{$0.003^{a}$} \\
\hline & Definitive & 8 & $15-75$ & 22 & 32 & 53 & \\
\hline & $\begin{array}{l}\text { Temporary } \\
\text { during RT }\end{array}$ & 13 & $0-100$ & 15 & 40 & 87 & \\
\hline & Temporary use & 4 & $0-85$ & 17 & 72 & 82 & \\
\hline & Total & 110 & $0-100$ & 38 & 75 & 100 & \\
\hline \multirow[t]{5}{*}{ Sleep } & No & 85 & $0-100$ & 50 & 100 & 100 & \multirow[t]{5}{*}{0.207} \\
\hline & Definitive & 8 & $50-100$ & 50 & 62 & 8 & \\
\hline & $\begin{array}{l}\text { Temporary } \\
\text { during RT }\end{array}$ & 13 & $25-100$ & 68 & 100 & 100 & \\
\hline & Temporary use & 4 & $12.50-100$ & 21 & 75 & 100 & \\
\hline & Total & 110 & $0-100$ & 50 & 100 & 100 & \\
\hline \multirow[t]{5}{*}{ Fatigue } & No & 85 & $0-100$ & 58 & 75 & 100 & \multirow[t]{3}{*}{0.199} \\
\hline & Definitive & 8 & $25-100$ & 25 & 37 & 75 & \\
\hline & $\begin{array}{l}\text { Temporary } \\
\text { during RT }\end{array}$ & 13 & $0-100$ & 29 & 83 & 100 & \\
\hline & Temporary use & 4 & $0-100$ & 0 & 37 & 93 & \\
\hline & Total & 110 & $0-100$ & 41 & 75 & 100 & \\
\hline
\end{tabular}

Abbreviations: max., maximum; Min., minimum; RT, radiotherapy; SWAL-QOL, Quality of Life in Swallowing Disorders (SWAL-QOL) questionnaire. Note: $p$ value according to Kruskal-Wallis test.

${ }^{\mathrm{a}} \mathrm{p}<0.05$.

Table 7 Association between SWAL-QOL and the permanence of tracheotomy

\begin{tabular}{|l|l|l|l|l|l|l|}
\hline Variable & $\begin{array}{l}\text { Not } \\
\text { definitively }\end{array}$ & $\begin{array}{l}\text { Not temporarily } \\
\text { during RT }\end{array}$ & $\begin{array}{l}\text { Not in } \\
\text { temporary } \\
\text { use }\end{array}$ & $\begin{array}{l}\text { Definitively or } \\
\text { temporarily } \\
\text { during RT }\end{array}$ & $\begin{array}{l}\text { Definitively in } \\
\text { temporary use }\end{array}$ & $\begin{array}{l}\text { Temporarily during } \\
\text { RT in temporary use }\end{array}$ \\
\hline Burden & 0.115 & 0.116 & 0.0525 & 0.051 & 0.332 & 0.908 \\
\hline $\begin{array}{l}\text { Symptom } \\
\text { frequency }\end{array}$ & 0.068 & 0.032 & 0.0212 & 0.514 & 0.865 & 0.821 \\
\hline Food selection & $0.005^{\text {a }}$ & 0.0190 & 0.199 & 0.091 & 0.275 & 0.773 \\
\hline Communication & 0.019 & $0.002^{\text {a }}$ & $0.002^{\text {a }}$ & 0.628 & 0.059 & 0.110 \\
\hline Fear & 0.009 & 0.068 & 0.346 & 0.239 & 0.481 & 0.818 \\
\hline Social & $0.002^{\text {a }}$ & 0.022 & 0.308 & 0.636 & 0.267 & 0.690 \\
\hline
\end{tabular}

Abbreviations: max., maximum; Min., minimum; RT, radiotherapy; SWAL-QOL, Quality of Life in Swallowing Disorders questionnaire. Note: $p$ value according to Mann-Whitney test adjusted by Bonferroni correction.

${ }^{\mathrm{a}} \mathrm{p}=0.008512$.

can point out some characteristics that are not measured by pathophysiological parameters. ${ }^{29,30}$

\section{Conclusion}

The effects of radiotherapy and chemoradiotherapy on swallowing function are relevant on dysphagia-related QOL. The harm caused by dysphagia from 6 to 12 months after treatment is recognized by patients with advanced tumors. The type of treatment (concomitant combined radiotherapy and chemotherapy), use of nasogastric tube, tracheotomy, and continuation of tobacco and alcohol habits contribute to decreased QOL. The SWAL-QOL questionnaire is a useful and sensible tool to detect difficulties and perspectives of patients with head and neck cancer. 


\section{Acknowledgment}

This study was sponsored by the National Council of Technological and Scientific Development (CNPq) as Scientific Initiation grant.

\section{References}

1 Pauloski BR, Rademaker AW, Logemann JA, et al. Relationship between swallow motility disorders on videofluorography and oral intake in patients treated for head and neck cancer with radiotherapy with or without chemotherapy. Head Neck 2006; 28(12):1069-1076

2 Eisbruch A, Lyden T, Bradford CR, et al. Objective assessment of swallowing dysfunction and aspiration after radiation concurrent with chemotherapy for head-and-neck cancer. Int J Radiat Oncol Biol Phys 2002;53(1):23-28

3 Graner DE, Foote RL, Kasperbauer JL, et al. Swallow function in patients before and after intra-arterial chemoradiation. Laryngoscope 2003;113(3):573-579

4 Kotz T, Costello R, Li Y, Posner MR. Swallowing dysfunction after chemoradiation for advanced squamous cell carcinoma of the head and neck. Head Neck 2004;26(4):365-372

5 Platteaux N, Dirix P, Dejaeger E, Nuyts S. Dysphagia in head and neck cancer patients treated with chemoradiotherapy. Dysphagia 2010;25(2):139-152

6 Nuyts S, Dirix P, Clement PM, et al. Impact of adding concomitant chemotherapy to hyperfractionated accelerated radiotherapy for advanced head-and-neck squamous cell carcinoma. Int J Radiat Oncol Biol Phys 2009;73(4):1088-1095

7 Nguyen NP, Moltz CC, Frank C, et al. Dysphagia following chemoradiation for locally advanced head and neck cancer. Ann Oncol 2004;15(3):383-388

8 McHorney CA, Bricker DE, Kramer AE, et al. The SWAL-QOL outcomes tool for oropharyngeal dysphagia in adults: I. Conceptual foundation and item development. Dysphagia 2000;15(3):115-121

9 McHorney CA, Bricker DE, Robbins J, Kramer AE, Rosenbek JC, Chignell KA. The SWAL-QOL outcomes tool for oropharyngeal dysphagia in adults: II. Item reduction and preliminary scaling. Dysphagia 2000;15(3):122-133

10 McHorney CA, Robbins J, Lomax K, et al. The SWAL-QOL and SWAL-CARE outcomes tool for oropharyngeal dysphagia in adults: III. Documentation of reliability and validity. Dysphagia 2002; 17(2):97-114

11 Portas JG. Validação para a língua portuguesa-brasileira dos questionários: qualidade de vida em disfagia (SWAL-QOL) e satisfação do paciente e qualidade do cuidado no tratamento da disfagia (SWAL-CARE) [Dissertação]. São Paulo, Brazil: Fundação Antônio Prudente; 2009

12 Rinkel RN, Verdonck-de Leeuw IM, Langendijk JA, van Reij EJ, Aaronson NK, Leemans CR. The psychometric and clinical validity of the SWAL-QOL questionnaire in evaluating swallowing problems experienced by patients with oral and oropharyngeal cancer. Oral Oncol 2009;45(8):e67-e71

13 Gillespie MB, Brodsky MB, Day TA, Lee FS, Martin-Harris B. Swallowing-related quality of life after head and neck cancer treatment. Laryngoscope 2004;114(8):1362-1367
14 Nguyen NP, Frank C, Moltz CC, et al. Impact of dysphagia on quality of life after treatment of head-and-neck cancer. Int J Radiat Oncol Biol Phys 2005;61(3):772-778

15 van Bokhorst, de van der Schuer, van Leeuwen PA et al. The impact of nutritional status on the prognoses of patients with advanced head and neck cancer. Cancer 1999;86(3):519-527

16 Shune SE, Karnell LH, Karnell MP, Van Daele DJ, Funk GF. Association between severity of dysphagia and survival in patients with head and neck cancer. Head Neck 2012;34(6):776-784

17 Frowen J, Cotton S, Corry J, Perry A. Impact of demographics, tumor characteristics, and treatment factors on swallowing after (chemo) radiotherapy for head and neck cancer. Head Neck 2010;32(4): 513-528

18 Langendijk JA, Doornaert P, Rietveld DH, Verdonck-de Leeuw IM, Leemans CR, Slotman BJ. A predictive model for swallowing dysfunction after curative radiotherapy in head and neck cancer. Radiother Oncol 2009;90(2):189-195

19 Koiwai K, Shikama N, Sasaki S, Shinoda A, Kadoya M. Validation of the Total Dysphagia Risk Score (TDRS) as a predictive measure for acute swallowing dysfunction induced by chemoradiotherapy for head and neck cancers. Radiother Oncol 2010;97(1):132-135

20 List MA, Siston A, Haraf D, et al. Quality of life and performance in advanced head and neck cancer patients on concomitant chemoradiotherapy: a prospective examination. J Clin Oncol 1999;17(3): 1020-1028

21 Saltman B, Kraus DH, Szeto H, et al. In vivo and in vitro models of ionizing radiation to the vocal folds. Head Neck 2010;32(5):572-577

22 Kim JP, Khalmuratova R, Jeon SY, et al. Quantitative analysis of myosin heavy chain expression change in laryngeal muscle after irradiation in rats. Yonsei Med J 2011;52(1):158-164

23 Lazarus CL. Effects of chemoradiotherapy on voice and swallowing. Curr Opin Otolaryngol Head Neck Surg 2009;17(3):172-178

24 Langendijk JA, Doornaert P, Verdonck-de Leeuw IM, Leemans CR, Aaronson NK, Slotman BJ. Impact of late treatment-related toxicity on quality of life among patients with head and neck cancer treated with radiotherapy. J Clin Oncol 2008;26(22):3770-3776

25 Murry T, Madasu R, Martin A, Robbins KT. Acute and chronic changes in swallowing and quality of life following intraarterial chemoradiation for organ preservation in patients with advanced head and neck cancer. Head Neck 1998;20(1):31-37

26 Langius JAE, van Dijk AM, Doornaert P, et al. More than $10 \%$ weight loss in head and neck cancer patients during radiotherapy is independently associated with deterioration in quality of life. Nutr Cancer 2013;65(1):76-83

27 Mouw KW, Solanki AA, Stenson KM, et al. Performance and quality of life outcomes for T4 laryngeal cancer patients treated with induction chemotherapy followed by chemoradiotherapy. Oral Oncol 2012;48(10):1025-1030

28 So WK, Chan RJ, Chan DN, et al. Quality-of-life among head and neck cancer survivors at one year after treatment-a systematic review. Eur J Cancer 2012;48(15):2391-2408

29 Queija DdosS, Portas JG, Dedivitis RA, Lehn CN, Barros APB. Swallowing and quality of life after total laryngectomy and pharyngolaryngectomy. Braz J Otorhinolaryngol 2009;75(4): 556-564

30 McHorney CA, Martin-Harris B, Robbins J, Rosenbek J. Clinical validity of the SWAL-QOL and SWAL-CARE outcome tools with respect to bolus flow measures. Dysphagia 2006;21(3):141-148 